\title{
Release of vasoactive intestinal peptide in the dumping syndrome
}

\author{
G R SAGOR, M G BRYANT, M A GHATEI, R M KIRK, S R BLOOM
}

\begin{abstract}
To determine the effect of gastric surgery on the plasma vasoactive intestinal peptide (VIP) concentration, 13 patients with gastrectomy and seven controls were given an oral hypertonic load (200 $\mathrm{ml} 50 \%$ glucose solution). Blood was taken at intervals during the test for measurement of VIP and blood glucose concentrations and packed cell volume. At the same time observations were made on the occurrence of dumping symptoms and a record kept of the pulse rate.

VIP values in the patients with gastrectomy were significantly increased by glucose ingestion, while these did not alter in controls $(p<0.001)$. There was a highly significant correlation between the rate of rise in plasma VIP concentration and the rates of rise in packed cell volume $(r=0.85 ; p<0.001)$ and blood glucose concentration $(\mathbf{r}=0.76 ; \mathbf{p}<0.01)$ in patients with gastrectomy. Changes in packed cell volume and blood glucose values and the occurrence of dumping symptoms during the test were significantly different when postoperative patients were compared with controls $(\mathbf{p}<0.001, \mathbf{p}<0.005$, and $p<0.001$ respectively). Furthermore, when the patients with gastrectomy were divided into those without symptoms and those with dumping after meals the latter group showed a significantly greater rise of VIP $(p<0.05)$.

Despite the increased plasma VIP concentrations observed during dumping, VIP cannot be taken as the sole factor in the pathogenesis of the dumping syndrome.
\end{abstract}

Royal Free Hospital, London NW3 2QG

G R SAGOR, FRCS, senior surgical registrar (during 1980 honorary senior registrar, department of medicine, Royal Postgraduate Medical School)

R M KIRK, MS, FRCS, consultant surgeon

Royal Postgraduate Medical School, London W12 0HS

M G BRYANT, BSC, biochemist

M A GHATEI, MPHIL, biochemist

$S$ R BLOOM, MD, FRCP, reader in medicine

\section{Introduction}

The dumping syndrome is generally accepted as due to the rapid passage of hyperosmolar nutriments into the upper small bowel, causing a transfer of fluid from the vascular compartment into the intestine, to produce an isosmotic intestinal content, with a resultant fall in plasma volume. ${ }^{1}$ This mechanism has been suggested as the cause of the observed faintness, dizziness, sweating, palpitations, abdominal distension, and diarrhoea. Other mechanisms have been proposed, however, and include the release of humoral agents such as serotonin ${ }^{2}$ and bradykinin ${ }^{3}$ from the distended bowel. Neurotensin, an ileal gut hormone with vasomotor properties, has also been implicated. ${ }^{4}$

Infusion studies of vasoactive intestinal peptide (VIP) in man and pigs $^{5}{ }^{6}$ have reproduced some of these features-namely, a rise in pulse rate, a decrease in diastolic blood pressure, and watery diarrhoea. We therefore decided to see if there was any alteration in plasma VIP concentration in the dumping syndrome.

\section{Patients and methods}

We studied 20 subjects (table I). Thirteen were patients who had been treated one to 18 months before by total or subtotal gastrectomy for carcinoma of the stomach; all were in good health. Seven subjects who had not had gastric surgery served as controls. Six of the patients with gastrectomy admitted to regular symptoms of dumping after meals, though in only one was this particularly troublesome.

All subjects were studied semirecumbent after an overnight fast. Serial blood samples for measurement of VIP and blood glucose concentrations and packed cell volume were taken via an indwelling cannula placed in a large antecubital vein. Samples of $10 \mathrm{ml}$ for hormone estimations were taken into heparinised tubes containing

TABLE I-Mean ages and weights of subjects studied (_SEM)

\begin{tabular}{lccc}
\hline & $\begin{array}{c}\text { Total gastrectomy } \\
\text { group } \\
(\mathrm{n}=6)\end{array}$ & $\begin{array}{c}\text { Subtotal gastrectomy } \\
\text { group } \\
(\mathrm{n}=7)\end{array}$ & $\begin{array}{c}\text { Controls } \\
(\mathrm{n}=7)\end{array}$ \\
\hline Age (years) & $56 \cdot 43 \cdot 2$ & $63 \cdot 1 \pm 2 \cdot 2$ & $59 \cdot 1 \cdot 1 \cdot 8^{*}$ \\
Weight (kg) & $55 \cdot 6 \pm 7.7$ & $64 \cdot 9 \pm 3.3$ & $67 \cdot 1.3 \cdot 5^{*}$
\end{tabular}

* Not significantly different from patients with gastrectomy. 
$200 \mu \mathrm{l}$ aprotinin (Trasylol $20 \times 10^{6}$ kallikrein inactivator units). These were centrifuged immediately and the plasma stored at $-20^{\circ} \mathrm{C}$ until assay.

Each patient was asked to drink $200 \mathrm{ml} 50 \%$ glucose solution over two minutes. Blood samples were taken 15 minutes and immediately before glucose ingestion and $15,30,45,60,90$, and 120 minutes afterwards. Throughout the test dumping symptoms or signs, such as abdominal pain or distension, sweating, diarrhoea, and faintness, and pulse rate were recorded.

VIP radioimmunoassay-VIP was measured by the method of Mitchell and Bloom. ${ }^{7}$ Briefly, antisera were raised in rabbits with VIP conjugated to bovine serum albumin by the carbodiimide method. ${ }^{8}$ Iodination of VIP was by the lactoperoxidase technique. ${ }^{9}$ The antiserum, which reacted with the C-terminal region of VIP, was used at a final dilution of $1 / 320000$, and the assay could detect changes of $0.5 \mathrm{pmol} \mathrm{VIP} / 1$ of plasma $(1 \cdot 7 \mathrm{pg} / \mathrm{ml})$ with $95 \%$ confidence.

Gel-permeation chromatography-Fasting and post-stimulus plasma samples were subjected to gel-permeation chromatography on Sephadex G50 superfine. The column $(0.9 \times 60 \mathrm{~cm})$ was eluted with phosphate buffer $0.06 \mathrm{~mol} / \mathrm{l}, \mathrm{pH} 7 \cdot 0$, containing sodium chloride $0 \cdot 2$ mol/l, disodium ethylene diaminetetra-acetic acid $0.01 \mathrm{~mol} / \mathrm{l}$, and human serum albumin $0.14 \mathrm{~mol} / 1(1 \mathrm{~g} / 100 \mathrm{ml})$ at $4{ }^{\circ} \mathrm{C}$ for 18 hours. Flow was adjusted to $3 \mathrm{ml} / \mathrm{h}$ and $0.8 \mathrm{ml}$ fractions collected. The column was precalibrated with dextran blue $\left(\mathrm{mol} \mathrm{wt}>10^{6}\right)$, cytochrome C (approximate mol wt 12 000), natural porcine VIP (mol wt 3300), and sodium iodide ${ }^{-12.5}$ (mol wt 148) as molecular size markers and the two coloured markers and sodium iodide ${ }^{125}$ included in all sample elutions for internal calibrations. All fractions between the dextran blue marker and a point equal to two column volumes of buffer through the column were assayed for immunoreactive VIP content using the whole volume of each fraction in the assay.

Packed cell volume was determined with a Coulter model $S$ counter.

Blood glucose concentration was measured by the glucose oxidase method. ${ }^{10}$

Statistical-Student's $t$ test for unpaired data was used for group analysis and results expressed as mean and standard error of mean. The method of least squares was employed for the correlations.

\section{Results}

Plasma VIP-Figure 1 shows the changes in plasma VIP concentrations during the test. There was no significant difference between the two types of gastrectomy (total and subtotal), and these were therefore grouped together. The average rate of rise of plasma VIP

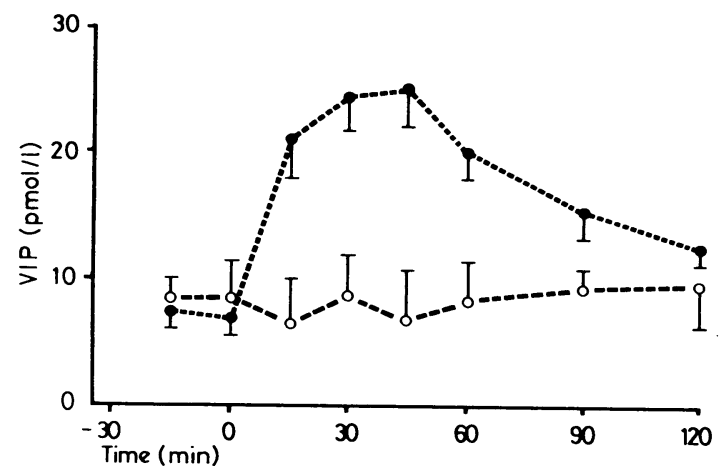

FIG 1 -Mean $( \pm$ SEM) plasma VIP concentrations after oral glucose. $=$ Patients with gastrectomy: $O=$ controls.

Conversion: SI to traditional units-Plasma VIP: $1 \mathrm{pmol} / 1$ $\approx 3.3 \mathrm{pg} / \mathrm{ml}$.

concentrations measured from basal values to 30 minutes after oral glucose was 0.58 t. $0.1 \mathrm{pmol} / \mathrm{l} / \mathrm{min}(19 \pm 0.3 \mathrm{pg} / \mathrm{ml} / \mathrm{min})$ in the gastrectomy group and $0.04 \pm 0.02 \mathrm{pmol} / 1 / \mathrm{min}(0 \cdot 1+0.07 \mathrm{pg} / \mathrm{ml} /$ $\mathrm{min}$ ) in controls $(\mathrm{p}<0.001)$. On gel-permeation chromatography of both fasting-stimulated and glucose-stimulated plasma samples almost all the increase of immunoreactivity was observed to be in the same elution as the purified porcine VIP used to calibrate the column (fig 2).

Packed cell volume and blood glucose concentrations-Table II shows the changes in these values after ingestion of glucose. There was a rise
TABLE II-Mean changes in packed cell volume and blood glucose concentration after ingestion of glucose load $( \pm S E M)^{*}$

\begin{tabular}{|c|c|c|c|}
\hline & $\begin{array}{c}\text { Gastrectomy } \\
\text { group }(n=13)\end{array}$ & $\begin{array}{l}\text { Controls } \\
(\mathbf{n}=7)\end{array}$ & $\mathbf{p}$ \\
\hline $\begin{array}{l}\text { Packed cell volume: } \\
\text { Change }(\%) \\
\text { Rate of change }(\% / \mathrm{min})\end{array}$ & $\begin{array}{l}3.8 \pm 0.3 \\
0.1 \pm 0.01\end{array}$ & $\begin{array}{l}-0.6 \pm 0.47 \\
-0.02 \pm 0.01\end{array}$ & $\begin{array}{l}<0.001 \\
<0.001\end{array}$ \\
\hline $\begin{array}{l}\text { Blood glucose concentration: } \\
\text { Change (mmol/l) } \\
\text { Rate of change }(\mathrm{mmol} / \mathrm{min} / \mathrm{l})\end{array}$ & $\begin{array}{l}7.03 \pm 0.7 \\
0.2 \pm 0.02\end{array}$ & $\begin{array}{l}3 \cdot 2 \pm 0 \cdot 8 \\
0 \cdot 1 \pm 0 \cdot 02\end{array}$ & $\begin{array}{l}<0.005 \\
<0.005\end{array}$ \\
\hline
\end{tabular}

* Absolute change and rate of change measured from basal values to 45 minutes afte glucose ingestion (time of mean peak).

Conversion: SI to traditional units-Blood glucose: $1 \mathrm{mmol} / 1 \approx 18 \mathrm{mg} / 100 \mathrm{ml}$.

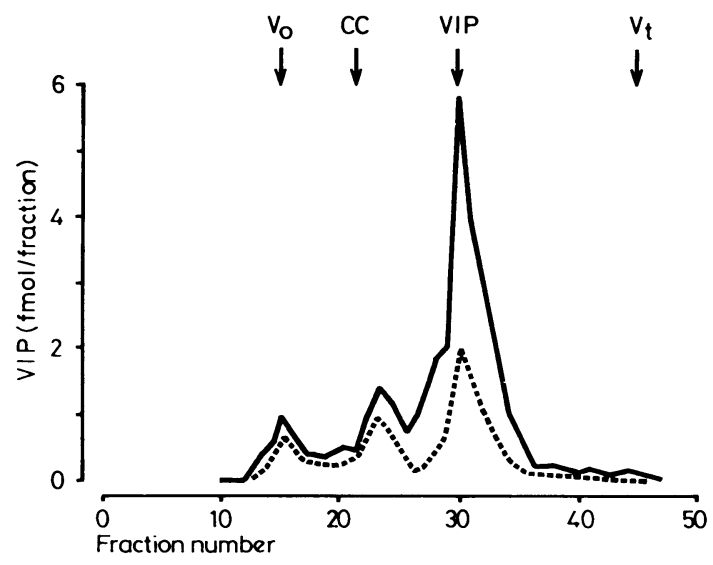

FIG 2-Representative gel-permeation chromatography profile of fasting-stimulated (- . - -) and glucose-stimulated (-) plasma immunoreactive VIP. $\mathrm{V}_{\mathrm{o}}=$ Void volume, $\mathrm{CC}$ Cytochrome $\mathrm{C}, \mathrm{VIP}=$ Elution position of porcine VIP. $\mathrm{V}_{\mathrm{t}}=$ Total volume of column.

Conversion: SI to traditional units-VIP: $1 \mathrm{fmol} / 1 \approx 3.3$ $\mathrm{pg} / \mathrm{ml}$.

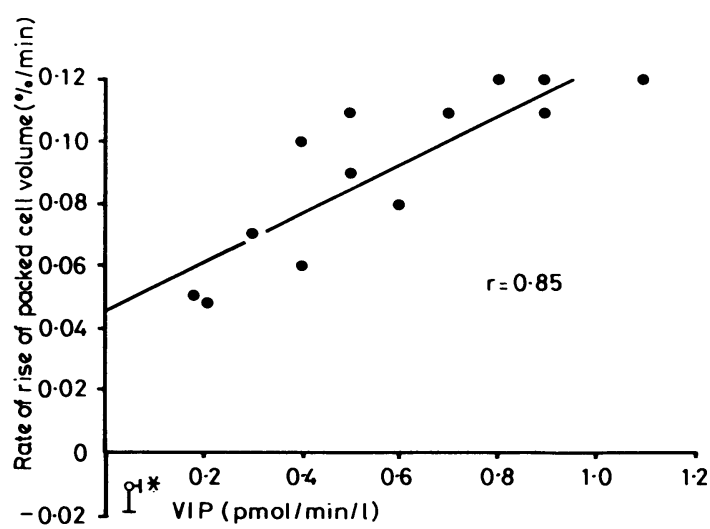

FIG 3 - Correlation of rate of increase in plasma VIP concentration with rate of change in packed cell volume after oral glucose in 13 patients with gastrectomy.

* Mean $\pm S E M$ in controls.

Conversion: SI to traditional units-VIP: $1 \mathrm{pmol} / 1 / \mathrm{min} \approx$ $3.3 \mathrm{pg} / \mathrm{ml} / \mathrm{min}$.

in packed cell volume in the gastrectomy group but a slight fall in the controls; the difference was highly significant $(p<0.001)$. Blood glucose concentration showed a significantly higher rise and greater rate of change in the gastrectomy group than in controls $(p<0.005)$.

Correlations-In the gastrectomy group there was a highly significant direct correlation between the rate of increase of VIP concentration and the rate of rise in packed cell volume $(r=0.85$, $\mathrm{n}=13, \mathrm{p}<0.001$ ) (fig 3). Similarly a significant correlation was found between the rates of increase in VIP and blood glucose concentrations $(\mathrm{r}=0 \cdot 76, \mathrm{n}=13, \mathrm{p}<0 \cdot 01$ ) (fig 4).

Relation to dumping symptoms-On dividing the patients with gastrectomy into those with dumping symptoms regularly after meals and those who were asymptomatic we found that the dumpers had 
higher VIP concentrations (fig 5) and a faster rate of rise of VIP concentration $0.7 \pm 0.1 \mathrm{pmol} / 1 / \mathrm{min}, 2.3 \pm 0.3 \mathrm{pg} / \mathrm{ml} / \mathrm{min}$ than the non-dumpers $0.4 \pm 0.1 \mathrm{pmol} / \mathrm{l} / \mathrm{min}, 1.3 \pm 0.3 \mathrm{pg} / \mathrm{ml} / \mathrm{min} ; \mathrm{p}<0.05)$. All these dumpers $(n=6)$ plus a further five patients with gastrectomy had dumping provoked by the oral glucose. Of these, eight had watery diarrhoea at about 30 minutes after glucose ingestion. Those experiencing diarrhoea included the six patients with a history of dumping routine after meals. None of the controls had dumping symptoms during the test.

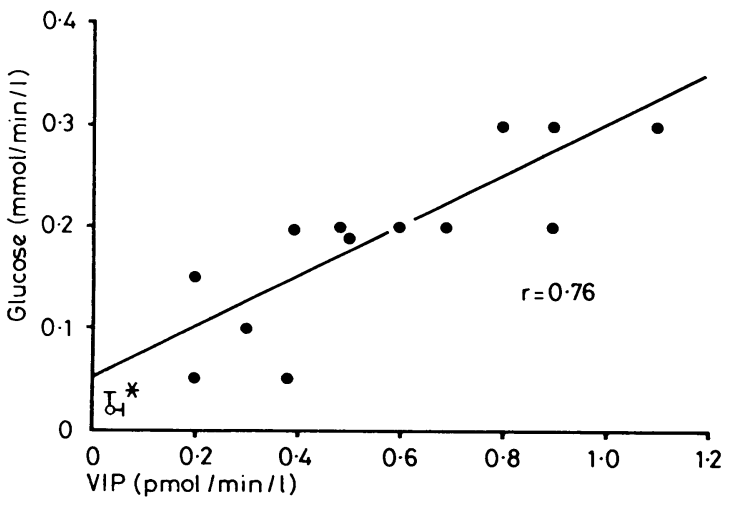

FIG 4-Correlation of rate of increase in plasma VIP concentration with rate of increase in blood glucose value after oral glucose in 13 patients with gastrectomy.

* Mean $\pm S E M$ in controls.

Conversion: SI to traditional units-Glucose: $1 \mathrm{mmol} / 1 / \mathrm{min}$ $\approx 18 \mathrm{mg} / \mathrm{ml} / \mathrm{min}$

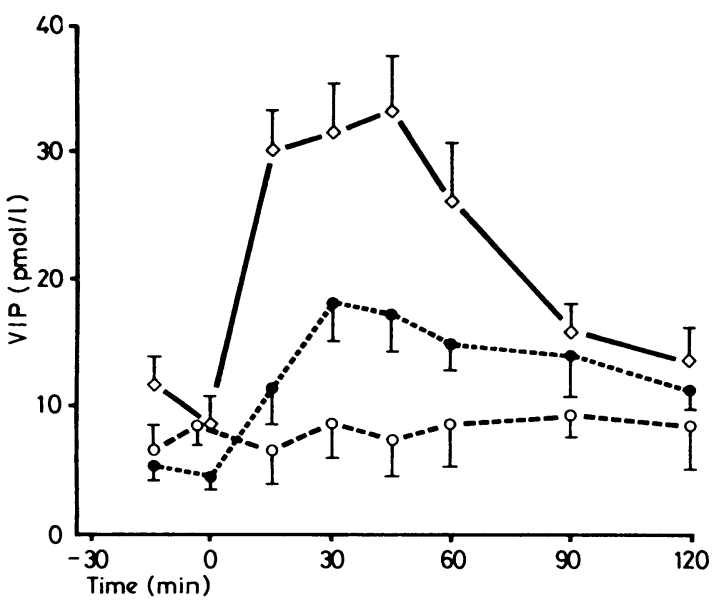

FIG 5-Mean ( \pm SEM) plasma VIP concentrations after oral glucose. $\diamond=$ Dumpers with gastrectomy. $\bigcirc=$ Non-dumpers with gastrectomy. $\mathrm{O}=$ Controls.

\section{Discussion}

Vasoactive intestinal peptide is a 28 amino-acid peptide, which may be isolated from the gut and brain.11 It is distributed in large quantities throughout the body and is found localised to the neural elements. Concentrations in the gastrointestinal tract are particularly high. VIP is thought to act as a neurotransmitter and a paracrine hormone, rather than in endocrine fashion. A small transitory rise occurs in plasma VIP after intraduodenal instillation of acid or hypertonic solutions, ${ }^{12}$ but VIP is not released in healthy subjects after a standard test meal.?

A major interest in this peptide in the circulation has centred on its role as a possible mediator in the watery diarrhoeahypokalaemia-achlorhydria syndrome (Verner-Morrison syndrome; pancreatic cholera), ${ }^{13}{ }^{14}$ in which an islet-cell adenoma of the pancreas is associated with severe watery diarrhoea, secondary hypokalaemia, and reduced acid output. This syndrome is usually caused by a VIP-secreting tumour (vipoma), and VIP concentrations in the plasma are over $60 \mathrm{pmol} / \mathrm{l}$ $(198 \mathrm{pg} / \mathrm{ml})$ during active diarrhoea.

In our study the rise in VIP concentrations in the gastrectomy group was accompanied by a significantly greater rise in blood glucose and packed cell volume and more frequent occurrence of symptoms of dumping than in the controls; there were also significant correlations between the changes in packed cell volume and blood glucose and the changes in VIP concentration in patients with gastrectomy after oral glucose. It is well established that oral hypertonic glucose causes a more rapid fall in plasma volume ${ }^{1}$ and a greater rise in blood glucose values ${ }^{15}$ in patients after gastric surgery than in normal subjects and that these changes are greater in postoperative patients with dumping symptoms than in asymptomatic patients after similar surgery. In this study, though plasma volume was not measured direct, changes in packed cell volume were regarded as a good index of plasma volume change. ${ }^{16}$ That the VIP measured was true VIP was shown by the increase of immunoreactivity on gel-permeation chromatography, which was observed to be in the same elution position as purified porcine VIP used to calibrate the column.

Our finding of a more rapid rise of VIP concentrations with higher peak values in the dumpers with gastrectomy than in the asymptomatic patients with gastrectomy, raises the question whether VIP plays a part in the pathogenesis of dumping. Indeed, VIP infusion in $\operatorname{man}^{4}$ produces certain features which are not dissimilar to those in the dumping syndrome-for example, a large and dose-dependent increase in pulse rate, with a lowering of diastolic blood pressure. These effects were attained at plasma VIP concentrations of above $100 \mathrm{pmol} / \mathrm{l}$ $(330 \mathrm{pg} / \mathrm{ml})$ and were the result of the vasodilator action of VIP. Similarly, VIP infusion into ambulant pigs $^{5}$ produced watery diarrhoea at plasma concentrations of around $70 \mathrm{pmol} / 1$ $(231 \mathrm{pg} / \mathrm{ml})$.

In our study the mean peak plasma VIP concentration attained during the test in dumpers with gastrectomy was $32 \cdot 4$ $\mathrm{pmol} / \mathrm{l}(106.9 \mathrm{pg} / \mathrm{ml})$. Although VIP concentrations in the postoperative group were significantly higher than in controls, they were below values required to produce circulatory effects and diarrhoea in the VIP-infusion studies and lower than VIP values found in the watery diarrhoea-hypokalaemia-achlorhydria syndrome. In those cases, however, there was no additional sudden reduction in plasma volume due to rapid osmotic shifts of fluid into the gut, nor concomitant rises of other vasoactive peptides such as neurotensin, ${ }^{4}$ as found in dumping.

Thus, although we found raised plasma VIP concentrations during dumping, we must conclude that VIP alone does not fully explain the pathogenesis of this syndrome. Nevertheless, when the circulation is already compromised by reduced plasma volume and a rise in other vasoactive peptides, an increase of VIP, a powerful vasodilatory agent, may be a critical additional factor.

Mr G R Sagor is supported by a grant from the Stanley Thomas Johnson Foundation, Berne, Switzerland. We thank Miss C Kinch for typing the manuscript.

Requests for reprints should be addressed to: Dr S R Bloom, Department of Medicine, Royal Postgraduate Medical School, Du Cane Road, London W12 0HS.

\section{References}

1 Le Quesne LP, Hobsley M, Hand BM. The dumping syndrome. I. Factors responsible for the symptoms. Br Med F 1960;i:141-7.

2 Peskin GW, Miller LD. The role of serotonin in the "dumping syndrome." Arch Surg 1962;85:701-4.

3 Zeitlin IJ, Smith AN. 5-Hydroxindoles and kinins in the carcinoid and dumping syndromes. Lancet 1966;ii:986-91.

4 Bloom SR, Blackburn AM, Ebeid FH, Ralphs DNL. Neurotensin and the dumping syndrome. Gastroenterology 1978;14:1011.

5 Domscke S, Domscke W, Bloom SR, et al. Vasoactive intestinal peptide in man: pharmacokinetics, metabolic and circulatory effects. Gut 1978;19: 1049-53. 
${ }^{6}$ Modlin IM, Bloom SR, Mitchell SJ. The role of VIP in diarrhoea. Gut 1977;18:A418.

${ }^{7}$ Mitchell SJ, Bloom SR. Measurement of fasting and postprandial plasma VIP in man. Gut 1978;19:1043-8.

${ }^{8}$ Goodfriend TL, Levine L, Faoman GP. Antibodies to bradykinin and angiotensin: use of carbodiimide in immunology. Science 1964;144: 1344-6.

${ }^{2}$ Holohan KW, Murphy RF, Flanagan RWJ, Buchanan KD, Elmore DT Enzymatic iodination of the histidyl residue of secretin: radioimmunoassay of the hormone. Biochim Biophys Acta 1973;322:178-180.

10 Trinder P. Determination of glucose in blood using glucose oxidase with an alternative oxygen acceptor. Ann Clin Biochem 1969;6:24-7.

${ }^{11}$ Bryant MG, Polak JM, Modlin I, Bloom SR, Pearse AGE. Alburquerque RH. Possible dual role for vasoactive intestinal peptide as gastrointestinal hormone and neurotransmitter substance. Lancet 1976;i: 991-3.
12 Ebeid AM, Escourron J, Murray P, Fischer JE. Pathophysiology of VIP. In: Bloom SR, ed. Gut hormones. Edinburgh: Churchill Livingstone, 1980

${ }^{13}$ Bloom SR, Polak JM. VIP and the watery diarrhoea syndrome. Lancet 1973; ;ii:14-6.

14 Bloom SR. Vasoactive intestinal peptide, the major mediator in the WDHA (pancreatic cholera) syndrome: value of measurement in diagnosis and treatment. Digestive Diseases 1978;23:373-6.

15 Hobsley $M$, Le Quesne LP. The dumping syndrome II: cause of the syndrome and the rationale of its treatment. $B r$ Med $\mathcal{F} 1960 ;$ i:147-51.

16 Thomson JPS, Russell RCG, Hobsley M, Le Quesne LP. The dumping syndrome and the hydrogen ion concentration of the gastric contents. Gut 1974;15:200-6.

(Accepted 21 November 1980)

\title{
Oesophageal carcinoma demonstrated by whole-body nuclear magnetic resonance imaging
}

\author{
F W SMITH, J M S HUTCHISON, J R MALLARD, G JOHNSON, T W REDPATH, R D SELBIE, \\ ANNE REID, C C SMITH
}

\begin{abstract}
The quality of the images produced by nuclear magnetic resonance (NMR) imaging has steadily improved over the past five years. Images of the head, thorax, and abdomen have clearly shown the normal anatomy. A clinical trial of NMR imaging has therefore been started in Aberdeen to assess its diagnostic accuracy and compare it with conventional radiography and other imaging techniques. The first patient examined by whole-body NMR imaging had carcinoma of the oesophagus diagnosed on barium meal examination. A technetium-99msulphur colloid liver scan also showed hepatic metastases. NMR imaging showed a large tumour in the lower third of the oesophagus, and areas of increased proton spinlattice relaxation time $\left(T_{1}\right)$ on a section through the liver corresponded with the metastases shown on the radionuclide scan. Increased areas of $T_{1}$ were present in some vertebrae, and a technetium-99m bone scan confirmed the presence of bone metastases.

The NMR images in this patient compared well with the images from other techniques. The continuing clinical trial may show that NMR is an accurate diagnostic aid which will complement existing techniques for diagnosing intrathoracic and intra-abdominal conditions.
\end{abstract}

\footnotetext{
Department of Nuclear Medicine, Aberdeen Royal Infirmary, Foresterhill, Aberdeen AB9 2ZB

F W SMITH, FFR, DMRD, consultant in nuclear medicine

Department of Biomedical Physics and Bioengineering, University of Aberdeen, Aberdeen AB9 2ZD

J M S HUTCHISON, BSC, PHD, lecturer

J R MALLARD, DSC, FRSE, professor

G JOHNSON, BA, MSC, postgraduate student

T W REDPATH, BSC, MSC, postgraduate student

$R$ D SELBIE, BSC, research officer

ANNE REID, $M B$, CHB, research officer
}

Department of Medicine, Aberdeen Royal Infirmary, Foresterhill, Aberdeen AB9 2ZB

C C SMITH, MB, FRCP, consultant physician

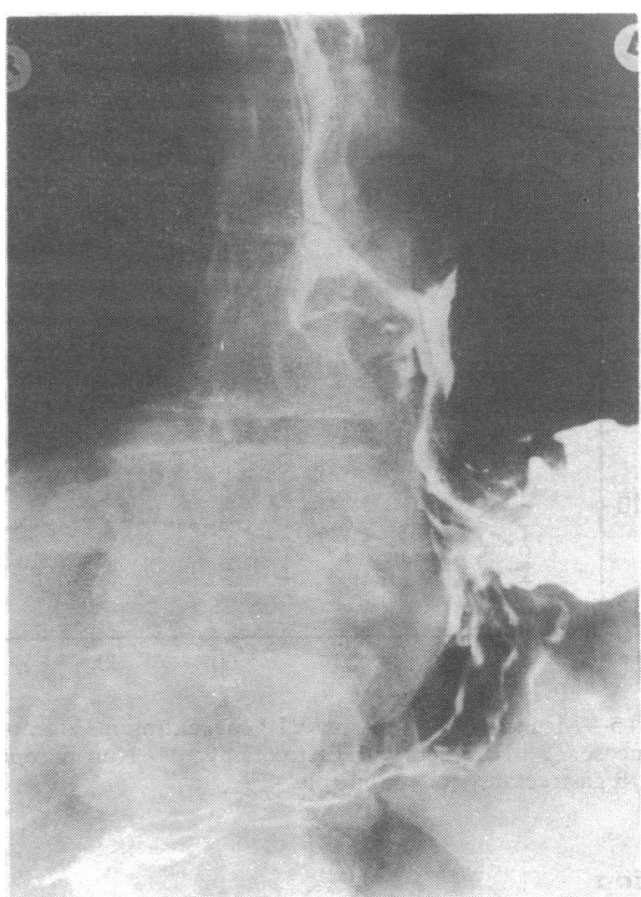

FIG 1-Anteroposterior view of lower oesophagus outlined with barium showing oesophageal carcinoma.

\section{Introduction}

During the past five years there has been a steady improvement in the image quality produced by nuclear magnetic resonance (NMR) imaging of the human body. Early NMR images were reported which showed the normal cross-sectional anatomy of a finger ${ }^{1}$ and of the wrist. ${ }^{2}$ Transverse tomographic sections of the skull, demonstrating the normal anatomy, have shown a steady improvement in image quality. ${ }^{34}$ Imaging of the thorax and abdomen has proved more difficult, and early images of the abdomen were disappointing, ${ }^{5}$ ' but recent images of the thorax and abdomen produced by our group in Aberdeen have given a clear demonstration of the normal anatomy. ${ }^{78}$ Transverse 